\section{Performance and digestibility of confined lambs fed with Babassu cake (Orbignya speciosa) as a substitute for elephant grass silage}

[Desempenho e digestibilidade de cordeiros confinados alimentados com torta de babaçu (Orbignya speciosa) em substituição à silagem de capim-elefante]

\author{
J.B. Luz ${ }^{1}$, D.I. Gomes ${ }^{2}$, E.R. Santos Neta' , R. Mezzomo ${ }^{2}$, \\ L.R.S. Oliveira ${ }^{2}$, R.C. Silva ${ }^{3}$, G.C. Reis ${ }^{3}$, K.S. Alves ${ }^{2}$
}

\author{
${ }^{1}$ Aluna de pós-graduação - Universidade Federal Rural da Amazônia - Parauapebas, PA \\ Universidade Federal Rural da Amazônia - Parauapebas, PA \\ ${ }^{3}$ Aluno de graduação - Universidade Federal Rural da Amazônia - Parauapebas, PA
}

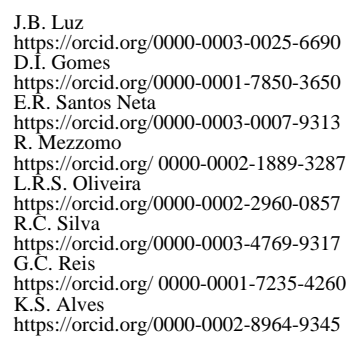

\title{
ABSTRACT
}

The objective of this study was to evaluate the effect of the partial replacement of elephant grass silage with babassu (Orbignya speciosa) on the performance, intake, digestibility, and carcass weight gain of sheep. Fifty-four castrated male lambs $(19.08 \pm 2.76 \mathrm{~kg})$ were distributed in a completely randomized design and administered one of the following treatments: $0.0,12.5,25.0,37.5$ or $50 \%$ dry matter $(\% \mathrm{DM})$ replacement of elephant grass silage with babassu cake. No difference $(\mathrm{P}>0.05)$ was observed in the dry matter, crude protein, and neutral detergent fiber intake, but the ether extract intake increased $(\mathrm{P}<0.05)$. The digestibility of the dry matter, neutral detergent fiber, and total digestible nutrients were unaffected. The crude protein digestibility decreased $(\mathrm{P}<0.05)$, and the ether extract digestibility increased with the replacement of the elephant grass. There were no changes in mean daily weight gain and carcass weight gain. In the carcasses, a linear increase was observed in the proportion of the ether extract, and the crude protein decreased. The replacement of the silage with the babassu cake by up to $50 \%$ did not change the performance of sheep, however it led to an increase in fat deposit in the carcass.

Keywords: by-product, intake, feedlot, ruminants

\section{RESUMO}

Objetivou-se avaliar a substituição parcial da silagem de capim elefante por torta de babaçu (Orbignya speciosa) sobre o desempenho, consumo, digestibilidade, composição química e ganho em peso de carcaça de ovinos. Cinquenta e quatro machos, castrados $(19,08 \pm 2,76 \mathrm{~kg})$ foram distribuídos em delineamento inteiramente casualizado e administrado um dos seguintes tratamentos: 0.0, 12.5, 25.0, 37.5 e $50 \%$ (\%MS) de substituição da silagem pela torta de babaçu. Não houve diferença (P>0.05) na ingestão de matéria seca, proteína bruta e fibra em detergente neutro, porém o consumo de extrato etéreo aumentou $(P<0.05)$. A digestibilidade da matéria seca, fibra em detergente neutro e nutrientes digestíveis totais não foram alterados, no entanto, os coeficientes de digestibilidade da proteína bruta reduziu $(P<0.05)$ e do extrato etéreo aumentou $(P<0.05)$, com a substituição. Não houve alterações no ganho de peso médio diário e ganho de peso em carcaça. Nas carcaças, observou-se aumento linear na proporção do extrato etéreo, no entanto a porcentagem de proteína bruta diminuiu. $O$ aumento no extrato etéreo da carcaça mostrou uma tendência linear. A substituição da silagem pela torta de babaçu em até $50 \%$ não alterou o desempenho de ovinos, porém levou a aumento na deposição de gordura na carcaça.

Palavras-chave: confinamento, consumo, ruminantes, subproduto

Recebido em 9 de janeiro de 2018

Aceito em 4 de dezembro de 2018

E-mail: janaina.ufra@hotmail.com 


\section{INTRODUCTION}

Brazil presents a variety of byproducts with promising characteristics and the potential for inclusion in animal diets, such as babassu cake (Orbignya speciosa), derived from the extraction of oil from its seeds (Sá et al., 2015; Santos Neta et al., 2017). The babassu cake is characterized as a bulky food with a low commercial value. This byproduct is easy to use due to its moisture content $(<15 \%)$, which allows it to be easily mixed with the other ingredients in feedlot animal diets (Luz et al., 2017). Another feature that makes its use attractive is the possibility of reducing costs with labor and equipment for making silage during periods of the year when fodder must be conserved for feeding feedlot animals.

Thus, the knowledge about the composition of the by-products, digestibility and animal performance becomes important, once the results obtained can help the farmer's decisions in reducing costs generated by the feeding of the confined animals. The objective of this study was to evaluate the babassu cake as a substitute for elephant grass silage on the performance, intake, digestibility, and chemical composition of the carcass and the carcass weight gain of feedlot sheep.

\section{MATERIALS AND METHODS}

The experiment was conducted at the Sheep Sector and at the Bromatology Analysis Laboratory of the Universidade Federal Rural da Amazônia - UFRA, Parauapebas, Pará, Brazil and was approved by the Ethics Committee on Animal Use (CEUA) of UFRA under protocol number 003/2014.

Fifty-four castrated, male, crossbred, Santa Inês lambs with initial body weights of $19.08 \pm 2.76 \mathrm{~kg}$ were used. The feedlot animals were acclimated to the experimental facilities and diets for 14 days before the beginning of the experiment. After this period, nine animals were randomly selected to determine the initial body composition. The remaining animals $(n=45)$ were housed in individual pens during the following 63-day experimental period.

The experimental design was completely randomized. The initial live weight was used as the covariable, and the five treatments consisted of replacement levels of elephant grass silage with babassu cake $(0.0,12.5,25.0,37.5$, and $50.0 \%$ ), with nine repetitions each.

The elephant grass silage (Pennisetum purpureum Schum, cv. Cameroon Roxo) originated from an established elephant grass field. The area has a small slope, and fertilization was carried out at each cut with $80 \mathrm{~kg}$ of nitrogen and $30 \mathrm{~kg}$ of potassium chloride per hectare. The grass was mechanically cut after reaching approximately $1.80 \mathrm{~m}$ of height and then after 100 days of regrowth; subsequently, it was chopped into $1.5 \mathrm{~cm}$ particles using an ensiling machine attached to a tractor, and the material was compacted in a stack silo after each unloading, without the use of any additives. Immediately after the material had been cut and compacted, the silo was sealed with a dual-sided tarpaulin and opened for use after 100 days of ensiling.

The diets (Table 1 and 2) were formulated to be isoproteic, adjusted with variations in the amount of urea, and formulated to meet the average daily requirements for weight gain of 200 g/animal/day for late-maturing animals $=0.4$ (Nutrient..., 2007). The calcium:phosphorus ratio of the diet was also adjusted with calcitic lime and dicalcium phosphate to achieve a $\mathrm{Ca}$ to $\mathrm{P}$ ratio of $1.4: 1$. The concentrate was composed of soybean meal, corn meal, calcitic lime, dicalcium phosphate, urea, and mineral mix.

The animals were weighed at the beginning of the experiment after fasting from solids for $16 \mathrm{~h}$. The diets were given at 8:00a.m. and 3:00p.m., with daily control of the quantity supplied, allowing 5 to $10 \%$ of leftovers. Individual intake was measured for 63 days. Samples of the leftovers and the ingredients of the diets were taken weekly, homogenized, properly labeled, and stored in a freezer at $-20^{\circ} \mathrm{C}$ for subsequent laboratory analysis.

Two digestibility trials were performed, the first one starting on day 10 and the second beginning on day 33 of the experimental period. Each digestibility trial period lasted 6 days, with 3 days to adapt the animals to the individual collection bags and 3 days to collect all feces. The collection bags were emptied three times a day (8:00am, 3:00p.m., and 11:00p.m.). During 
the trials, samples of the ingredients, leftovers, and feces were collected and homogenized, and a $20 \%$ aliquot of the weight of each sample was collected for subsequent laboratory analysis.

Samples of the leftovers, ingredients, and feces were dried in an oven at $55^{\circ} \mathrm{C}$ for 72 hours and then ground in a knife mill with a 1-ml sieve. The concentrations of dry matter (DM; INCTCA G-003/1 method), mineral matter (MM;
INCT-CA M-001/1 method), crude protein (CP; INCT-CA N-001/1 method), ether extract (EE; INCT-CA G-004/1 method), neutral detergent fiber corrected for ash and protein (NDFap; INCT-CA F-001/1 method), using heat-stable alpha-amylase without sodium sulfite, acid detergent fiber (ADF; INCT-CA F-003/1 method), and indigestible neutral detergent fiber (NDFi; INCT-CA F-008/1 method) were evaluated according to Detmann et al. (2012).

Table 1. Chemical composition of the main ingredients of experimental diets

\begin{tabular}{ccccc}
\hline Nutrientes, g/kg DM & Babassu cake & Corn meal & Soybean meal & Elephant grass silage \\
\hline Dry matter & 920.4 & 878.5 & 855.6 & 208.3 \\
Organic matter & 958.3 & 985.5 & 923.4 & 912.5 \\
Ash & 38.3 & 12.7 & 65.5 & 106.5 \\
Crude protein & 216.2 & 86.2 & 447.0 & 54.4 \\
Ether extract & 84.0 & 43.0 & 4.50 & 16.6 \\
Neutral detergent fiber $^{\mathrm{a}}$ & 593.4 & 143.9 & 104.2 & 610.3 \\
Acid detergent fiber & 424.9 & 34.5 & 96.2 & 504.0 \\
\hline
\end{tabular}

${ }^{\mathrm{a}}$ Corrected for ash and nitrogenous compounds

Table 2. Ingredients and chemical composition of the experimental diets

\begin{tabular}{cccccc} 
Item & \multicolumn{5}{c}{ Proportion of babassu cake, \% DM } \\
\cline { 2 - 6 } & Ingredient composition, g/kg of DM & 12.5 & 25.0 & 37.5 & 50.0 \\
\hline Elephant grass silage & 400.0 & 350.0 & 300.0 & 250.0 & 200.0 \\
Babassu cake & - & 50.0 & 100.0 & 150.0 & 200.0 \\
Soybean meal & 160.0 & 160.0 & 160.0 & 160.0 & 160.0 \\
Corn meal & 409.5 & 408.8 & 408.0 & 407.0 & 406.5 \\
Urea & 15.0 & 13.0 & 11.0 & 9.0 & 7.0 \\
Mineral mixture & 8.0 & 8.0 & 8.0 & 8.0 & 8.0 \\
Dicalcium phosphate & 4.5 & 4.5 & 4.5 & 4.5 & 4.5 \\
Limestone calcitic & 3.0 & 5.7 & 8.5 & 11.5 & 14.0 \\
& Chemical composition , g/kg of DM & & & \\
Dry matter, g/kg de NM & 610.0 & 645.7 & 681.4 & 717.1 & 752.8 \\
Organic matter & 932.2 & 932.2 & 932.0 & 931.7 & 931.7 \\
Crude protein & 170.4 & 172.9 & 175.3 & 177.7 & 180.2 \\
Ether extract & 25.0 & 28.3 & 31.7 & 35.0 & 38.4 \\
Neutral detergent fiber ${ }^{\mathrm{a}}$ & 320.2 & 319.3 & 318.3 & 317.2 & 316.3 \\
Acid detergent fiber & 231.1 & 227.1 & 223.2 & 219.2 & 215.2 \\
Indigestible neutral detergent fiber & 138.2 & 132.1 & 126.1 & 120.1 & 114.0 \\
Metabolizable energy, Mcal/kg & 2.8 & 2.8 & 2.7 & 2.7 & 2.7 \\
Ca:P & $1.4: 1$ & $1.4: 1$ & $1.4: 1$ & $1.4: 1$ & $1.4: 1$ \\
\hline
\end{tabular}

${ }^{\mathrm{a}}$ Corrected for ash and nitrogenous compounds

The in vivo apparent digestibility for the dry matter and nutrients were obtained by the difference between the amounts of nutrients ingested and those excreted in the feces. The total digestible nutrient intake was obtained by the formula TDN $=$ digestible $\mathrm{CP}+($ digestible $\mathrm{EE} \times 2.25)+$ total digestible carbohydrates. For the presentation of the results, the mean nutrient digestibility of the two collection periods was considered.

On day 63 of the experimental period, the animals were subjected to a fast from solids for 16h. They were then sacrificed by concussion with subsequent sectioning of the jugular and carotid vessels. The slaughter followed good 
animal welfare practices, and the slaughtering procedures were in accordance with the Animal Products Inspection Regulation (Brasil, 1997). After slaughter, the carcasses were weighed and cooled in a refrigerated room at $4^{\circ} \mathrm{C}$ for $24 \mathrm{~h}$, then the carcasses were weighed again, divided into two half-carcasses, and the left side was ground and homogenized, with a sample being collected for chemical analysis of the carcass. Subsequently, the samples were dried in an oven at $55^{\circ} \mathrm{C}$ for 72 hours and pre-defatted by successive washes in petroleum ether. The predefatted samples were ground in a ball mill and stored in containers for further analysis of the dry matter and mineral matter, crude protein, and ether extract, according to the methodologies described for the food samples.

The initial chemical composition of the carcasses of the animals was estimated using equations generated from the carcass weight data and the amount of each nutrient obtained from the carcass samples of the reference animals, which were slaughtered in the beginning of the experiment. Subsequently, the chemical composition of the weight gain was determined while considering the final nutrient concentration minus the initial nutrient concentration.

The data were subjected to analysis of variance and regression using Statistical Analysis System software (SAS Institute Inc., Cary, NC, USA). The initial live weight was used as a covariate, and the data were analyzed as a function of the level of inclusion of babassu cake in the experimental diets. The sum of squares of treatments in contrasts analysis was decomposed into two contrasts: linear $(-2,-1,0,+1,+2)$ and quadratic effects $(+2,-1,-2,-1,+2)$ for the significance of the model $(\mathrm{P}<0.05)$. The mathematical model is represented by $\mathrm{Y}_{\mathrm{ijk}}=\mu+$ $\mathrm{T}_{\mathrm{i}}+\mathrm{M}_{\mathrm{j}}+\mathrm{e}_{\mathrm{ijk}}$, in which $\mu=$ overall mean, $\mathrm{T}_{\mathrm{i}}=$ effect of the diets, $M_{j}=$ effect of the covariate, and $\mathrm{e}_{\mathrm{ijk}}=$ residual random error.

\section{RESULTS}

No difference ( $\mathrm{P}>0.05$; Table 3 ) was observed in the intake of dry matter, crude protein, and neutral detergent fiber, but the ether extract intake increased linearly $(\mathrm{P}<0.05)$ with the replacement of elephant grass silage with babassu cake. The digestibility of dry matter, neutral detergent fiber, and total digestible nutrients were not influenced $(\mathrm{P}>0.05)$ by the level of inclusion of the babassu cake. However, the crude protein digestibility decreased linearly $(\mathrm{P}<0.05)$, and the ether extract digestibility increased linearly $(\mathrm{P}<0.05$; Table 3$)$ with each one percentage point replacement of the elephant grass silage with the babassu cake increasing digestibility by 0.17 percentage points.

Table 3. Intake and digestibility of dry matter and nutrients of sheep fed with babassu cake

\begin{tabular}{|c|c|c|c|c|c|c|c|c|}
\hline \multirow{2}{*}{ Itens } & \multicolumn{5}{|c|}{ Proportion of babassu cake, \% DM } & \multirow{2}{*}{ SEM } & \multicolumn{2}{|c|}{$P$ Value $^{\mathrm{a}}$} \\
\hline & 0 & 12.5 & 25 & 37.5 & 50 & & $\mathrm{~L}$ & $\mathrm{Q}$ \\
\hline \multicolumn{9}{|c|}{ Intake, g/day } \\
\hline Dry matter & 982.47 & 993.23 & 954.28 & 969.07 & 1013.69 & 51.17 & 0.812 & 0.525 \\
\hline Crude protein & 177.22 & 182.84 & 175.10 & 176.02 & 184.73 & 9.35 & 0.779 & 0.668 \\
\hline Ether extract ${ }^{b}$ & 25.38 & 29.00 & 30.97 & 31.52 & 31.96 & 1.70 & 0.004 & 0.219 \\
\hline Neutral detergent fiber $_{\text {ap }}$ & 286.00 & 286.57 & 278.52 & 288.76 & 304.09 & 1.61 & 0.445 & 0.422 \\
\hline $\begin{array}{l}\text { Total digestible } \\
\text { nutriente }\end{array}$ & 625.83 & 636.65 & 588.99 & 560.41 & 694.40 & 48.13 & 0.691 & 0.148 \\
\hline \multicolumn{9}{|c|}{ Intake, \% Body Weight } \\
\hline Dry matter & 3.91 & 3.89 & 3.77 & 3.69 & 3.94 & 0.14 & 0.735 & 0.267 \\
\hline Neutral detergent fiber ${ }_{a p}$ & 1.13 & 1.12 & 1.10 & 1.10 & 1.18 & 0.04 & 0.648 & 0.215 \\
\hline \multicolumn{9}{|c|}{ Digestibility, \% } \\
\hline Dry matter & 64.88 & 66.56 & 64.71 & 60.36 & 63.06 & 1.62 & 0.710 & 0.940 \\
\hline Crude protein ${ }^{c}$ & 78.93 & 75.20 & 72.40 & 71.59 & 70.73 & 2.13 & $<0.001$ & 0.326 \\
\hline Ether extract ${ }^{\mathrm{d}}$ & 74.36 & 79.22 & 80.34 & 81.57 & 83.48 & 1.53 & $<0.001$ & 0.306 \\
\hline Neutral detergent fiber $_{a p}$ & 35.69 & 36.82 & 39.25 & 34.46 & 42.25 & 3.83 & 0.121 & 0.294 \\
\hline Total digestible nutrient & 65.95 & 67.96 & 66.48 & 62.54 & 64.47 & 1.50 & 0.093 & 0.651 \\
\hline
\end{tabular}

${ }^{\mathrm{a}}$ Contrasts Linear (L) and quadratic (Q)

${ }^{b} \mathrm{y}=26.63+0.12549 x\left(\mathrm{r}^{2}=0.17\right)$;

${ }^{c} \mathrm{y}=77.77234-0.15990 \mathrm{x} \quad\left(\mathrm{r}^{2}=0.17\right)$

$\mathrm{d}_{\mathrm{y}}=75.54078+0.17084 \mathrm{x}\left(\mathrm{r}^{2}=0.29\right)$. 
The replacement of up to $50 \%$ of elephant grass silage with the babassu cake did not change the average daily gain or carcass weight gain $(\mathrm{P}>$ 0.05; Table 4). A linear increase was observed in the proportion of ether extract, whereas the percentage of crude protein decreased $(\mathrm{P}>0.05$;
Table 4) in the carcass of the animals fed higher levels of babassu cake. Sheep that received higher levels of babassu cake deposited more $(\mathrm{P}>$ $0.05)$ ether extract in the carcass, exhibiting an increase of $1.673 \mathrm{~kg}$ of ether extract in the carcass compared to the control treatment.

Table 4. Productive performance and chemical composition of the carcass and chemical composition of carcass weight gain of sheep feed with babassu cake

\begin{tabular}{|c|c|c|c|c|c|c|c|c|}
\hline \multirow{2}{*}{ Item } & \multicolumn{5}{|c|}{ Proportion of babassu cake, \% DM } & \multirow[t]{2}{*}{ SEM } & \multicolumn{2}{|c|}{$P$ Value $^{\mathrm{a}}$} \\
\hline & 0 & 12.5 & 25 & 37.5 & 50 & & $\mathrm{~L}$ & Q \\
\hline \multicolumn{9}{|l|}{ Performance } \\
\hline Final body weight, $\mathrm{kg}$ & 31.15 & 31.86 & 31.57 & 33.37 & 32.14 & 0.87 & 0.211 & 0.585 \\
\hline Average daily gain, g/day & 191.40 & 202.91 & 198.34 & 226.91 & 207.20 & 13.83 & 0.209 & 0.573 \\
\hline Final carcass weight, $\mathrm{kg}$ & 14.32 & 14.07 & 14.57 & 14.81 & 14.58 & 0.34 & 0.272 & 0.865 \\
\hline Carcass weight gain, g/day & 104.72 & 100.71 & 108.59 & 112.45 & 108.73 & 5.77 & 0.280 & 0.873 \\
\hline Feed conversion, $\mathrm{kg} \mathrm{DM} / \mathrm{kg}$ ADG & 5.11 & 4.89 & 4.85 & 4.27 & 4.89 & - & - & - \\
\hline \multicolumn{9}{|c|}{ Chemical composition of the carcass } \\
\hline Moisture, \% & 56.28 & 53.82 & 53.36 & 54.28 & 52.74 & 1.12 & 0.064 & 0.477 \\
\hline Ash, \% & 3.43 & 4.34 & 4.30 & 3.73 & 4.10 & 0.62 & 0.501 & 0.184 \\
\hline Ether extract, $\%^{\mathrm{b}}$ & 21.46 & 22.86 & 23.59 & 24.87 & 25.63 & 1.41 & 0.039 & 0.821 \\
\hline Crude protein, $\%^{\mathrm{c}}$ & 18.82 & 17.79 & 18,73 & 17.39 & 17.51 & 0.44 & 0.043 & 0.920 \\
\hline \multicolumn{9}{|c|}{ Chemical composition of the weight gain } \\
\hline Moisture, $\mathrm{kg}$ & 7.89 & 7.55 & 7.02 & 8.26 & 6.94 & 0.67 & 0.647 & 0.991 \\
\hline Ash, kg & 0.49 & 0.78 & 0.76 & 0.64 & 0.70 & 0.21 & 0.437 & 0.185 \\
\hline Ether extract, $\mathrm{kg}^{\mathrm{d}}$ & 5.37 & 6.14 & 6.13 & 6.80 & 7.01 & 0.52 & 0.038 & 0.652 \\
\hline Crude protein, $\mathrm{kg}$ & 3.13 & 2.95 & 3.13 & 2.98 & 2.80 & 0.24 & 0.432 & 0.727 \\
\hline
\end{tabular}

\footnotetext{
${ }^{\mathrm{a}}$ Contrasts Linear $(\mathrm{L})$ and quadratic $(\mathrm{Q})$

$\mathrm{b}_{\mathrm{y}}=21.86374+0.07702 \mathrm{x} \quad\left(\mathrm{r}^{2}=0.10\right)$

${ }^{c} \mathrm{y}=18.73719-0.02625 \mathrm{x}\left(\mathrm{r}^{2}=0.10\right)$

$\mathrm{d}_{\mathrm{y}}=5.56238+0.03022 \mathrm{x}\left(\mathrm{r}^{2}=0.09\right)$
}

\section{DISCUSSION}

The linear increase in the ether extract intake was possibly due to the higher lipid content present in the babassu cake, which increased the content of this component in the diets, promoting greater intake by the animals when fed with increasing levels of the byproduct. However, the increase in the ether extract content of the diets was not enough to affect the intake of dry matter and other nutrients since the diets contained levels lower than the maximum amounts of 50 to $70 \mathrm{~g} / \mathrm{kg}$ of dry matter recommended for ruminants, as values above these have detrimental effects on the ruminal microbiota (Palmquist and Jenkins, 1980). In addition, the experimental diets had similar amounts of the remaining nutrients and dry matter.

The higher digestibility of the ether extract (Table 3) may have reflected the higher intake of this nutrient and the quality of the fatty acids in the babassu cake. Specifically, regarding the digestibility of the crude protein, the observed decrease may have been caused by the high content of neutral detergent insoluble protein, which accounted for $47.97 \%$ of the crude protein of the babassu cake (Santos Neta et al., 2017). Therefore, even if the byproduct has $21.62 \%$ crude protein, much of it is unavailable to the animal.

The use of babassu cake in replacement of elephant grass silage did not alter animal performance (Table 4), which can be attributed to the similar intake of the animals (Table 2) observed in this study, as animal performance is a direct function of the digestible dry matter intake, such that was $60-90 \%$ of its variation results from changes in intake and $10-40 \%$ from changes in digestibility (Mertens, 1994).

Regarding the chemical composition of the carcass, the animals fed babassu cake showed an increase of 4.36 percentage points in the ether extract content of the carcass and a reduction of 1.35 percentage points in the crude protein content compared to those that consumed only 
elephant grass silage as roughage. These results were likely caused by the higher intake and digestibility of ether extract (Table 3) wick together cause an increase in the amount of digestible ether extract.

The animals that received babassu cake exhibited an increased deposition of ether extract (Table 4) in the chemical composition of the carcass weight gain without a change in the amount of deposited protein. This finding, and the minor crude protein digestibility, suggest that nitrogen was less efficiently used with the use of babassu cake (Luz et al., 2017) due to a possible difference in the profile of absorbed amino acids, protein deamination to ammonia, and nitrogen recycling, which may have led to greater deposition of ether extract in the carcass. In addition, a higher ether extract intake and digestibility (Table 3) and lower crude protein digestibility occurred with babassu cake in the diets, with the babassu resulting in a greater amount of ether extract in the carcass.

\section{CONCLUSION}

The replacement of elephant grass silage with babassu cake by up to $50 \%$ is a roughage food option to be used in lamb confinements, without reducing animal performance.

\section{ACKNOWLEDGMENTS}

We thank the Conselho Nacional de Pesquisa e Desenvolvimento Científico e Tecnológico (CNPq) for financial support.

\section{REFERENCES}

BRASIL. Ministério da agricultura, Pecuária e Abastecimento. Regulamento da Inspeção Industrial e Sanitária de Produtos de Origem Animal. Decreto n. 30.691, que Regulamento da Inspeção Industrial e Sanitária de Produtos de Origem Animal. Diário Oficial da União. Brasília, Brasília, 5 jul. 1997.

DETMANN, E.; SOUZA, M.A.; VALADARES FILHO, S.C. et al. Métodos para análise de alimentos - INCT - Ciência Animal. Visconde do Rio Branco: Suprema, 2012. 214p.

LUZ, J.B.; ALVES, K.S.; MEZZOMO, R. et al. Carcass characteristics and meat quality of lambs fed babassu cake (Orbignya speciosa) as a replacement for elephant grass silage. Trop. Anim. Health. Prod., v.49, p.113-119, 2017.

MERTENS, D.R. Regulation of forrage intake. In: FAHEY Jr.; G.C. (Ed.). Forrage quality, evaluation and utilization. Madison: American Society of Agronomy, 1994. p.450-493.

NUTRIENT requirements of small ruminants. Washington, DC: National Academies Press, 2007. 362p.

PALMQUIST, D.L.; JENKINS, T.C. Fat in lactation rations: review. J. Dairy Sci., v.63, p.114, 1980.

SÁ, H.C.M.; BORGES, I.; MACEDO JUNIOR, G.L. et al. Consumo e comportamento ingestivo de ovinos mestiços alimentados com torta do babaçu (orbignya spp.). Biosci. J., v.31, p.107$113,2015$.

SANTOS NETA, E.R.S.; ALVES, K.S.; MEZZOMO, R. et al. Behavior of sheep fed babassu cake (Orbygnia speciosa) as a substitution for elephant grass silage. Anim. Sci. J., v.88, p.1171-1177, 2017. 